\title{
EchoGéo
}

$18 \mid 2011$

Varia

\section{The Map of Watchful Architecture}

\section{Garrett Carr}

\section{OpenEdition}

Journals

\section{Édition électronique}

URL : https://journals.openedition.org/echogeo/12673

DOI : 10.4000/echogeo. 12673

ISSN : 1963-1197

\section{Éditeur}

Pôle de recherche pour l'organisation et la diffusion de l'information géographique (CNRS UMR 8586)

Référence électronique

Garrett Carr, «The Map of Watchful Architecture », EchoGéo [En ligne], 18 | 2011, mis en ligne le 05 décembre 2011, consulté le 31 juillet 2021. URL : http://journals.openedition.org/echogeo/12673 ; DOI : https://doi.org/10.4000/echogeo.12673

Ce document a été généré automatiquement le 31 juillet 2021.

EchoGéo est mis à disposition selon les termes de la licence Creative Commons Attribution - Pas d'Utilisation Commerciale - Pas de Modification 4.0 International (CC BY-NC-ND) 


\section{The Map of Watchful Architecture}

\section{Garrett Carr}

\section{Introduction}

On Thursday the $15^{\text {th }}$ of April 1976 the $3^{\text {rd }}$ Battalion of the British Army's Parachute Regiment was deployed in South Armagh, commanded by Brigadier Peter Morton. This part of Northern Ireland was often referred to as 'Bandit Country', a hotbed of Irish Nationalist sentiment inside the United Kingdom, close to the border with the Republic of Ireland. It was a highly militarised landscape. Soldiers patrolled the lanes, army watchtowers observed from hilltops and helicopters cruised back and forth to the battalion's headquarters in Newry. Morton suggests that this helipad was, at the time, the busiest in Europe (Morton, 1989, p. 18). 
Illustration 1 - Romeo One One watchtower, Stugan Mountain, Sturgan Brae, Camlough, South Armagh, 1998

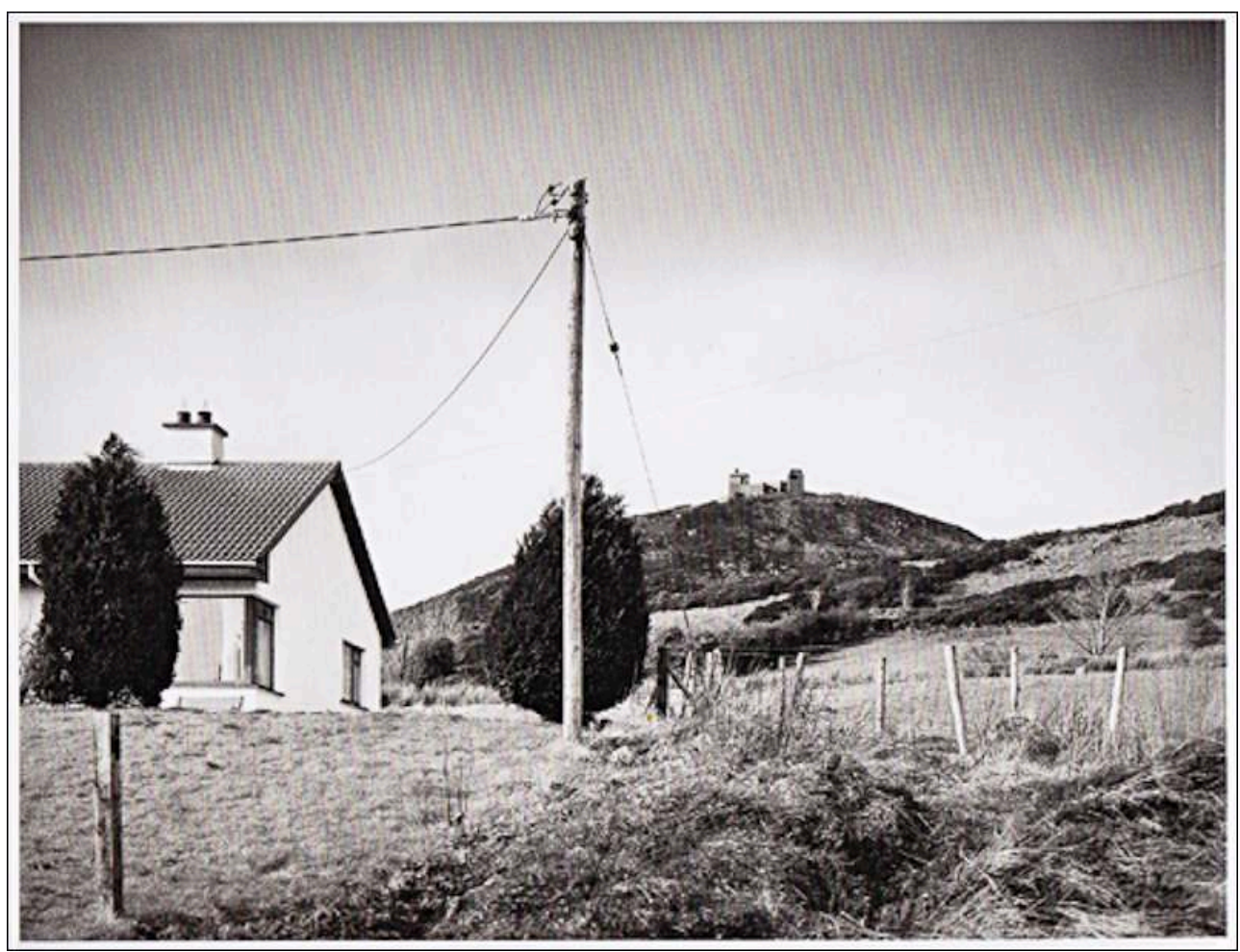

Source : Photographed by Jonathan Olley published in Castles of Ulster, Factotum, Belfast, 2007

2 This was during a long period of violence called 'the Troubles', a conflict driven by differing stances on the constitutional status of Northern Ireland. The border was often a Troubles' battleground and it was also its metaphor. Away from the border, in Northern Ireland's urban spaces, its symbolic value was being re-enacted in the demarcation of neighbourhoods and by regular acts of violence. The symbolic resonance of the Irish border meant little to Morton. He was more concerned with the tactical and practical difficulties of the actual border landscape. Crossing it was a convenient escape route for terrorists attacking his troops. Explosive devices were sometimes detonated from over the border or sniper fire received from there. In addition, it was easy for British troops to accidentally stray south of the border and cause diplomatic incidents. Much of Morton's tactical planning was around this question of how to manage the borderland. 
Illustration 2 - The Map of Watchful Architecture 1.0

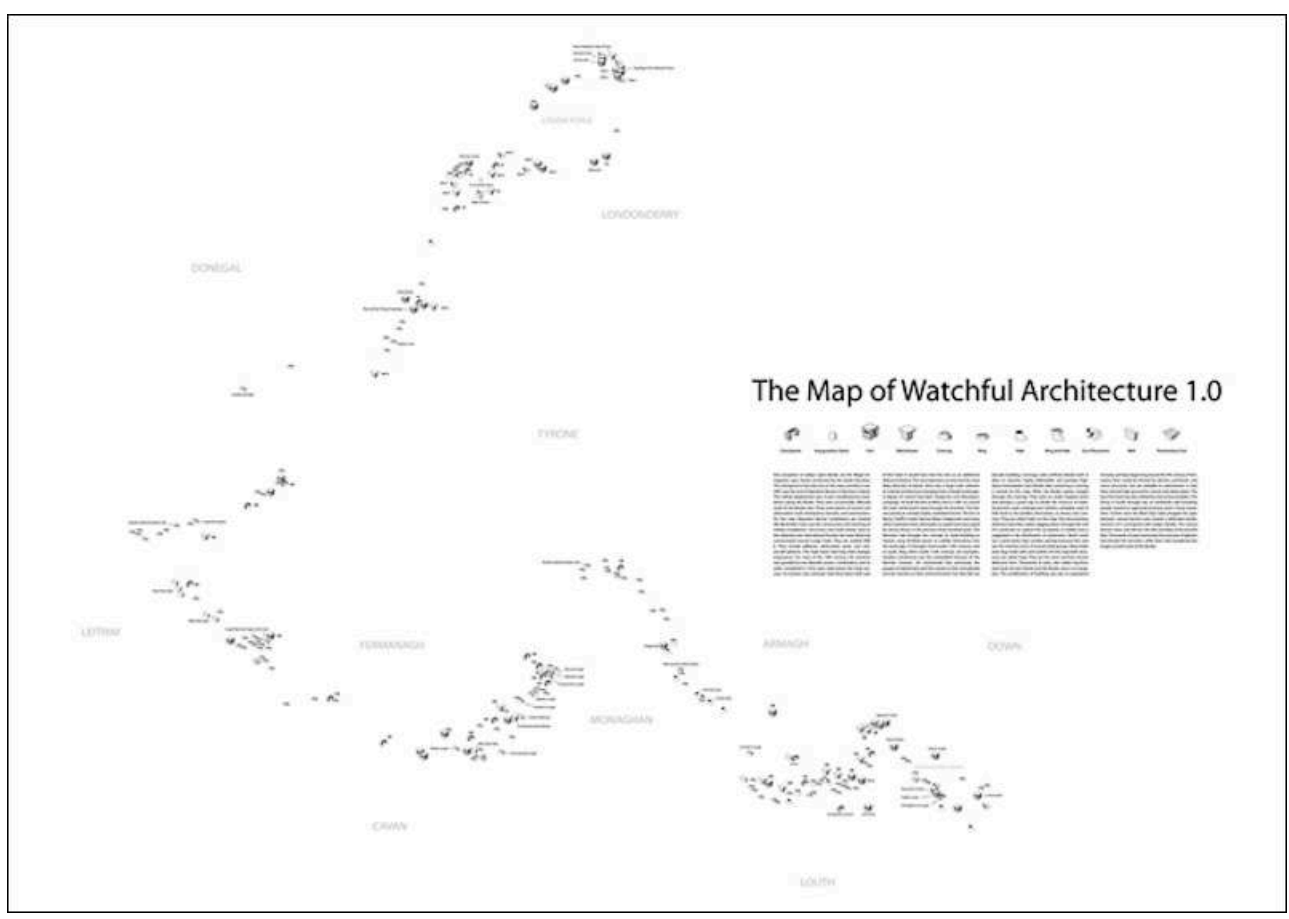

Source : Garrett Carr, www.newmapsofulster.net

3 Much of the Irish border's notoriety arose during in the later part of the $20^{\text {th }}$ century, around Morton's time. Yet, as this paper will attempt to show, this was far from the first time the management of the borderland had been a concern.

4 It had been an issue, on and off, for two thousand years. I will offer glimpses of that history and attempt to place the border, created in 1922, in the context of the borderland's longer past. This will be done via a map called The Map of Watchful Architecture. This is a map of defensive architecture built in Ireland's border corridor. Producing the map was a mode of research that attempted to reveal patterns on the borderland, focusing on the tangible form of the border on the ground. The design of the map is an attempt to question the overly simplistic cartographic sign of the borderline. A sign that applies us/them, here/there and other blunt binaries. The Map of Watchful Architecture attempts to form a new reading of the Irish border's demarcation and route, a new reading that may give rise to new thinking about how the border works and how it came to be.

\section{What is on the map}

The Irish border is usually represented on maps as a line but this is not the reality on the ground. Instead it is now, and has always tended to be, managed from strong points dotted along its length. Even during the Troubles its security never came close to the extreme lockdown found in Western Europe's border with the eastern bloc. The Irish border was never walled or fenced. Apart from on maps, it was never a line. The Map of Watchful Architecture portrays the border in a way more directly related to the facts on the ground, as a series of points, forming outposts, nets and rows. The map's lay-out 
was the result of simply deciding what constituted watchful architecture and plotting all instances on or close to today's borderline route.

6 With the exception of an inauguration stone and one police checkpoint, which is at consistent location but operates from a parked vehicle, The Map of Watchful Architecture concerns itself with built points, defensive architecture, along the border. That linear landscape has long been staked-out by the regularity of certain kinds of architecture. The map shows that controlling the borderland was a question preoccupying people since long before the partition in the $20^{\text {th }}$ century. To begin a selection of examples, the Black Pig's Dyke is series of ramparts, thought to have been built to protect tribes in Ulster against others in Connacht and Leinster, and has sections that correspond to today's border. These earthworks were created around the $1^{\text {st }}$ and $2^{\text {nd }}$ centuries AD. It was the first and last time any kind of attempt was made to seal the border, although in terms of today's engineering possibilities, it hardly came close. The dykes and ramparts vary greatly in construction and are not continuous; archaeological analysis suggests they never were. "Presumably in the past they linked naturally impassable areas created by bog or thick forest to form a defence, but one probably intended to keep cattle in, mark a frontier or control an important crossing rather than a continuously manned military position" (Mitchell/Ryan, 1997, p. 243).

7 The northern part of Co. Louth has one of the highest concentrations of souterrains in Ireland. They are described in the French term meaning under ground and most date from the Early Christian period. They were used for storage but the most precious things the builders of souterrains might have stored away were their own selves. During the Early Christian period slavery was rampant (Clinton, 2001). One documentary reference describes raiders digging down through the roof of a souterrain to capture the occupants (Edwards, 2005). Burrowed and hidden, souterrains may at first not seem watchful but they were in fact "the single most defensive structure of the Early Christian period" (Buckley, 1989, p. 35). They were a place to hide in the frequently marauded zones between early kingdoms and "it is possible to see early frontiers emerging from the distribution map of souterrains" (Buckley, 1989, p. 37).

Later came Norman castles and strong houses. Norman strife with the O'Neill dynasty, based in Ulster, meant plenty of Norman defensive construction around its borderlands. Many examples are still there to be seen, such as Co. Louth's, King John's Castle, built in the $12^{\text {th }}$ century, and Co. Donegal's, Greencastle, built in the $14^{\text {th }}$ century. In 1618 Londonderry and its walls were built. Further north and two centuries later, Martello Towers were constructed to watch over Lough Foyle. During the Second World War pillboxes and observation posts were constructed and manned north of the border, close to what was now an international frontier between the United Kingdom and the Free State, as the Republic of Ireland was then known. Later came the Troubles. The border operated as both a site of violence and symbol of the grimly binary opposition found at the root of the bloodshed. The military intervention was called Operation Banner and it involved the building of installations along the border, such as those in which Brigadier Morton lived and worked. These included checkpoints and watchtowers. All this adds up to what may be one of the longest unbroken traditions of defensive architecture anywhere in Western Europe, a tradition some thought finally broken as, in reaction to a cessation of violence, the last of the Operation Banner towers were deinstalled in 2007. But, take a bus journey south across the border and you might be pulled over by members of the Irish Republic's police force, the Garda Síochána. At 
checkpoints they check the identities of passengers in an attempt to stop illegal immigration via the United Kingdom. What about illegal immigrants who walk through the fields or along quiet lanes? They will have understood the border as it is even to those whom it would impede : defended points with gaps in-between.

Illustration 3 - Detail of The Map of Watchful Architecture 1.0

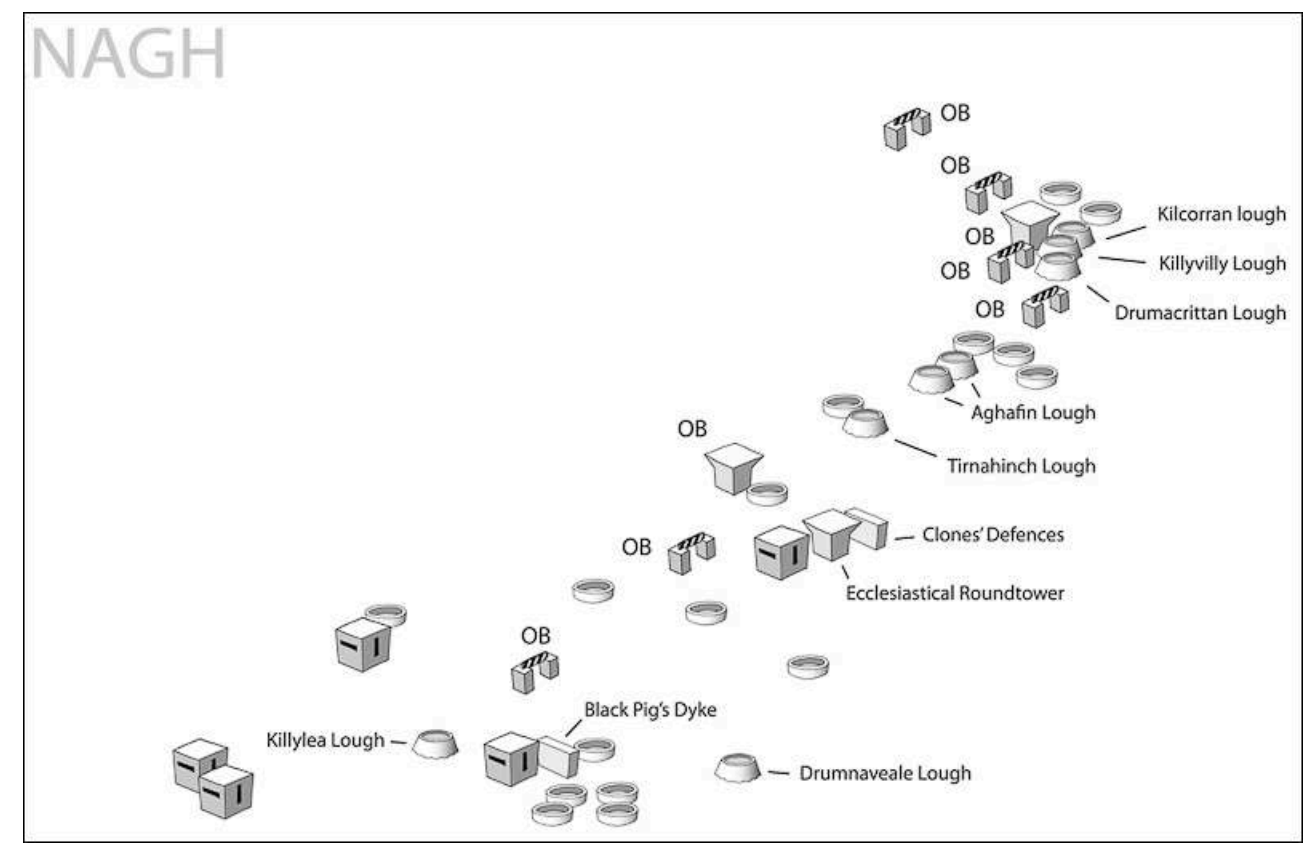

\section{Categorisation of forms}

The categorisation of elements on The Map of Watchful Architecture is based on their relationship to movement, that is to say human movement. Movement is perhaps the opposite impulse to that embedded in defensive points. The defensive buildings are like a series of posts hammered in the ground in an endless attempt to manage human shiftability. So, for example 'Checkpoints' and 'Walls' inhibit movement. 'Hides', make themselves invisible to people moving through, raiders for example. 'Watchtowers' observe movement and 'Crannogs' detach themselves from movement.

Illustration 4 - Categories from The Map of Watchful Architecture 1.0

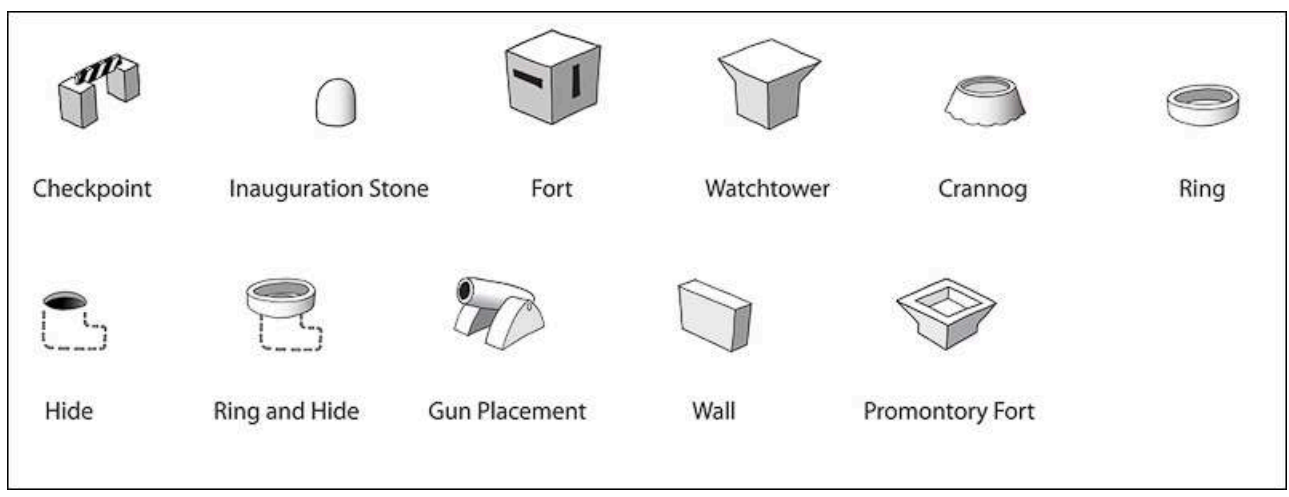


10 In Ireland, man-made islands in lakes are called crannogs. As far as we know the first use of the word crannog in this context comes from the Annals of Loch Ce, written in the 1220s (Fredengren, 2002). The logic of The Map of Watchful Architecture might have demanded renaming crannogs with something more directly descriptive, 'Built Islands' perhaps, in the way that souterrains have been called 'Hides'. This would be to remove the islands from history and to concentrate on their basic form. Renaming crannogs in the hunt for a more scientific title has been done before. A $19^{\text {th }}$-Century antiquarian W. G. Wood-Martin used the term lake-dwelling. D. H. Kelly called them stockaded islands. The $20^{\text {th }}$ century turned up new sub-divisions and corresponding terms; crannog cairn, log-platform and the German term Parkwerk. Then some named them water-settlements and wetland-settlements (Fredengren, 2002). In 1983 Chris Lynn argued that the term crannog should only be used for certain sites from the medieval period and later, those with a defensive function. He called attention to the fact that crannogs belonged in two distinct historical periods and to give them the same name implied a continuousness that was not really there. The all-embracing categorisation contributes to the notion that crannogs were being built continuously since the Stone Age. This proposition does not fit with our wider knowledge of historical population and cultural trends. He suggested the titles crannog and proto-crannog (Lynn, 1983, p. 54).

11 The problem, or perhaps the opportunity, here is the same one constantly encountered with the design of The Map of Watchful Architecture. Ancient sites will have been reused at different times, by different peoples and for different reasons. Often it cannot be said with certainty whether a site is Iron Age, Christian, or from a later period. It may have had a useful life stretching through many centuries. So it is with crannogs. At different times a crannog could have been a homestead, a workshop, a storehouse and a place of occasional refuge. The latter of that list would mean, in the context of The Map of Watchful Architecture, a crannog should be categorised as a 'Hide' and the hide symbol redesigned to embrace it. Crannogs are still used today for fishing and duck hunting. I suggest that this problem is an opportunity because it enables this new cartographic project to think down into the crannog and attempt to categorise its fundamental personality, the thing that keeps people returning to it. The map concludes that they were for removing oneself from movement. Even today's fly fisherman, rowing out to a crannog on a Sunday, might understand this. This kind of thinking is not archaeological. The map born out of it is not an archaeologist's map. Chris Lynn, who suggested the division between crannog and proto-crannog, might shudder at a map subtracting down to basic forms rather than establishing nuance and diversifying across time. "Lumping sites together in a loose, superficial classification implies that they are related ... The real situation is probably far more complex, and terminology must be designed to take variables into account" (Lynn, 1983, p. 54). The Map of Watchful Architecture is an attempt to roll all this back. Multiple forms are plainly lumped together into one. The map seeks to create relationships, even across many centuries.

The Swedish archaeologist Christina Fredengren (2002) studied crannogs. She accepted Lynn's evidence of non-continuousness but when it came to naming the form she distrusted the use of sub-divisions. As far as she was concerned, they were all crannogs. Her reasoning is partly why The Map of Watchful Architecture sticks with the $12^{\text {th }}$ century name and tries to make the 21st century bend to it. Lough Gara, in the NorthWest, was her case study. Fredengren devotes one chapter of her study to local people's 
contemporary relationship to local crannogs. She was disappointed by the common disinterest. To the locals, crannogs were ancient history and irrelevant. Fredengren saw her work as an attempt to reverse this trend. She wanted to put some wonder into crannogs. "We live in a constant replacement and deterritorialisation of meanings. One way to stop this never-ending chain of changing signifiers is to re-enchant the world, and to make places meaningful instead of commodified and exchangeable" (Fredengren, 2002, p. 298).

Ilustration 5 - Detail of The Map of Watchful Architecture 1.0

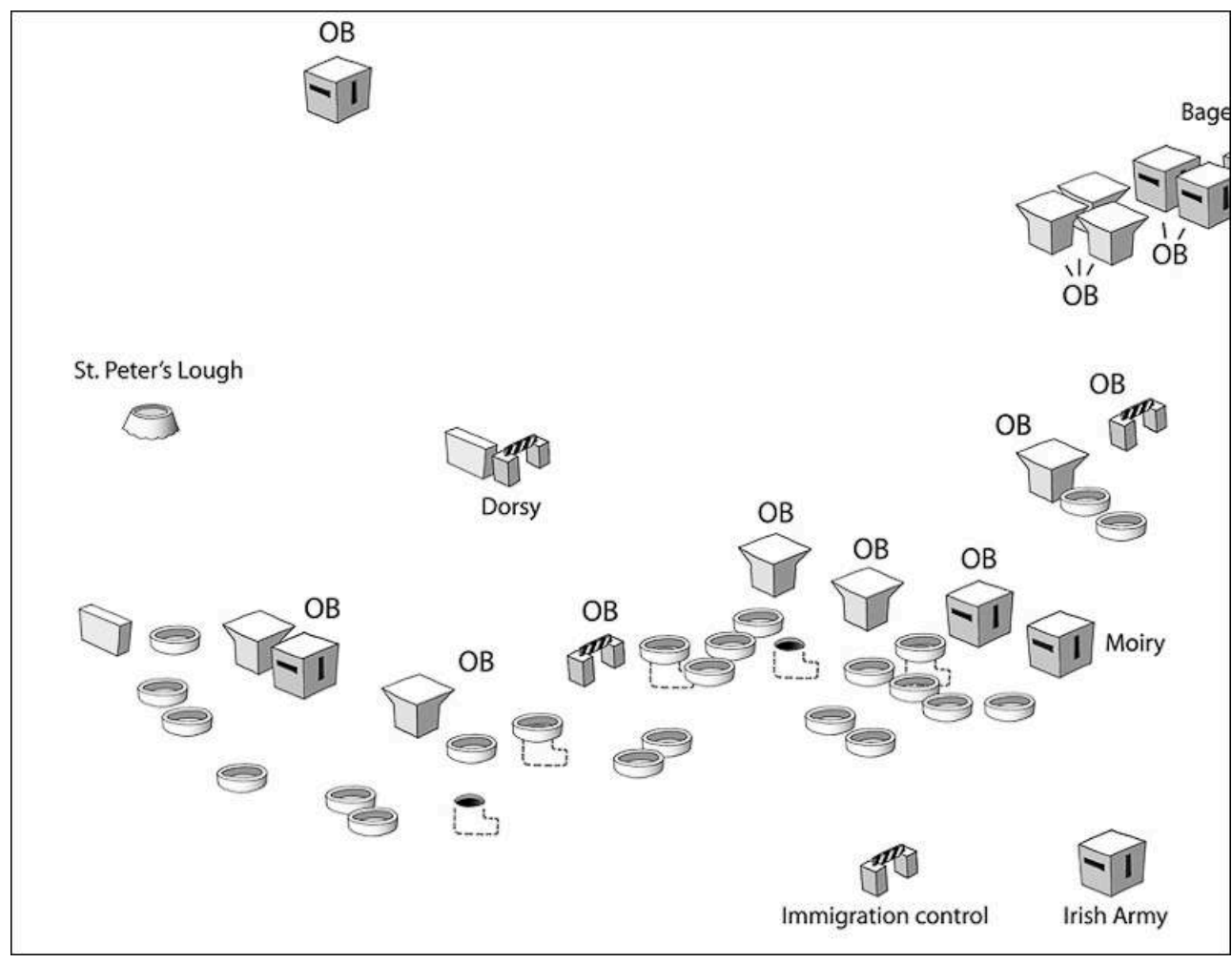

The Map of Watchful Architecture also attempts to make places meaningful. To cast some historical light on recent structures and, at the same time, re-enchant some old stones. As part of this mission the map represents certain structures, perhaps built centuries apart, as fundamentally the same. Not just crannogs. This is to encourage the map-reader to see perhaps unobvious relationships, throwing fresh light on both old and new. Take for another example, the Dorsey, close to the border in Southern Armagh, is a $1^{\text {st }}$-century earthwork. Steep banks funnelled travellers toward a narrow entrance point where they could be checked and perhaps taxed (Buckley, 1989, p. 26). It seems to have operated as an official entrance into northern territory. Dorsey means door or gate. Only a little to the south, the Garda Síochána checking for illegal immigrants may not know it but they are part of a 2000-year tradition. Here, instead of two categories, $1^{\text {st }}$-Century Gate and $21^{\text {st }}$-Century Immigration Control, the map has just one : 'Checkpoint'. To distinguish them chronologically textual labelling is used but the symbol is the same. In this way immigration control is revealed as the inheritor of a long tradition, while at the same time an ancient site is drawn into the contemporary dynamic. 


\section{The troubles and beyond}

In their time, the military watchtowers of Operation Banner were the focus of a great deal of dark fascination. Like the Maze Prison or the gable-end murals of Belfast and Londonderry the towers were "a visual shorthand for "the Troubles" (Purbrick, 2007, p. 59). When Brigadier Peter Morton was sent to head up 3rd Para in South Armagh there were 291 cross-border routes traversable by vehicle. As part of his duties Morton was overseeing $\mathrm{H} 1$ to $\mathrm{H} 43$, forty-three cross-border routes.

Illustration 6 - A military chart from Operation Banner, showing south Armagh border crossings

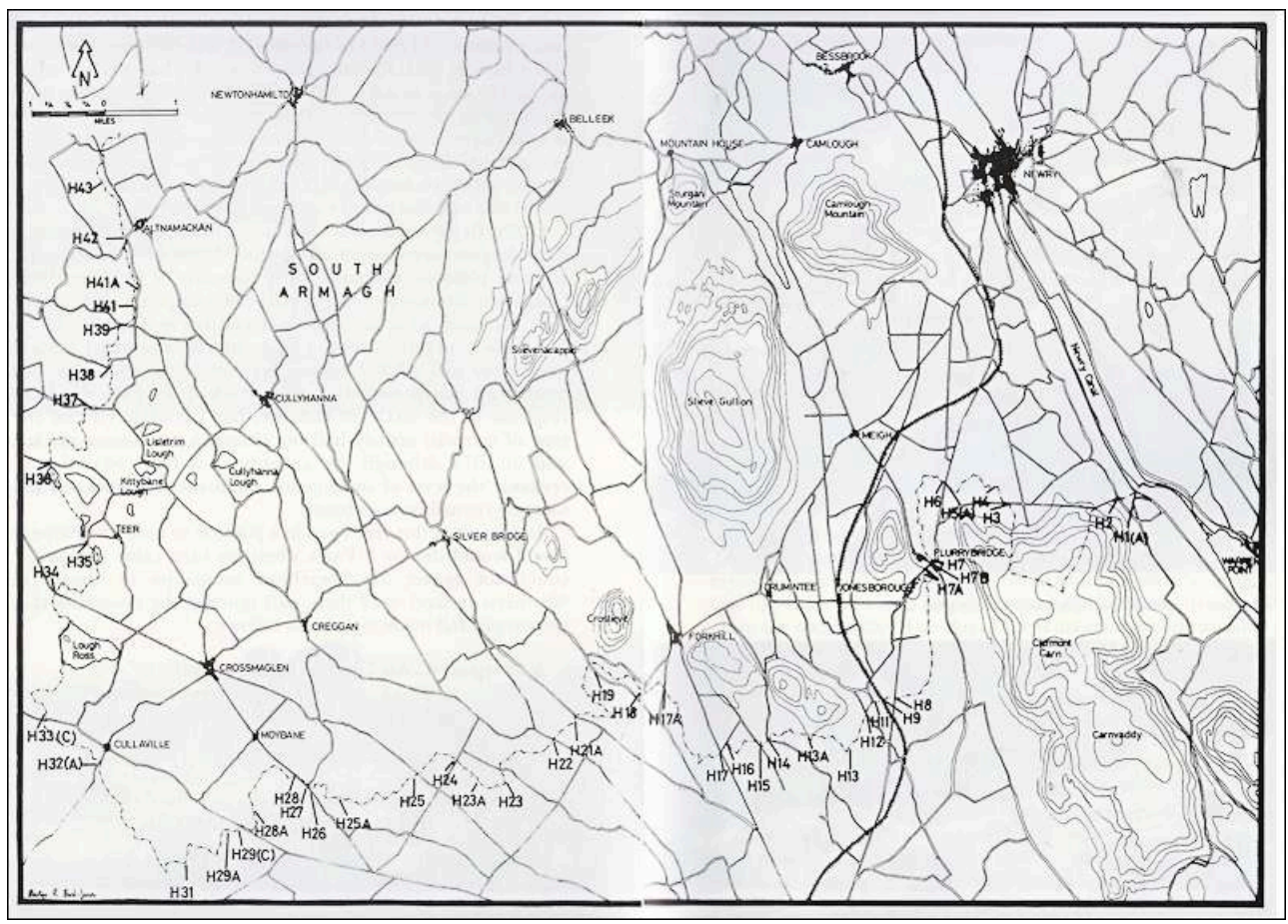

Brigadier Peter Morton area was ' $\mathrm{H}$ Division' hence the crossings $\mathrm{H} 1$ to $\mathrm{H} 43$.

Source : Crown Copyright, www.opsi.gov.uk.

These crossings brought logistical problems and real danger to Morton's troops but he never had much time for the idea of completely sealing the border. "[S]o often over the last almost two decades have we heard this expression from seemingly responsible figures, inside and outside Ulster, of all political persuasions. But what do they mean ?" (Morton, 1989, p. 31). The border corridor has few serious natural impediments. Farms straddle it and it runs down the middle of communities. The Irish border could not be sealed without a wall and a massive operation. One requiring :

303 miles of mesh fencing, 6-metre wide ploughed and harrowed strip, vehicle track, and Hinterland security fence. To these must be added about 360,000 explosive charges, 165 miles of vehicle hazards (ditches and dragon's teeth), 100 pill boxes, 100 concrete observation towers, command posts, earth bunkers, dogs and dog runs, arc lights etc. Clearly that is unacceptable ... (Morton, 1989, p. 32)

But in what sense "unacceptable" ? Ireland's border was only a third of the length of that between East and West Germany. It would have been expensive but it was possible to have built a properly-defended border. The problem was perhaps as much ideological as practical. Morton notes that any such construction would have been 
against democracy (Morton, 1989, p. 32). Winston Churchill's use of the 'Iron Curtain' metaphor was still reverberating across Europe and the government of the United Kingdom was not going to build anything comparable to that Soviet instrument. In 1976, shortly before Morton's deployment, Margaret Thatcher made a speech to the Finchley Conservatives. It was to become a well-known speech because it was when the soon-to-be Prime Minister embraced the title 'Iron-Lady.' Who better to do battle with the Iron Curtain? In the speech she said "Socialism is the denial of choice, the denial of choice for ordinary people in their everyday lives ... Socialists don't trust the people. Churchill did. We do" (Thatcher, 1976, online).

We trusted people ... but some people needed watching. Operation Banner watchtowers were often used to indicate something amiss in the standards of British democracy. Photographs of them were ominous enough to illustrate, and export, an image of oppression and injustice. Their location on hilltops, starkly contrasting what would be generally considered an attractive landscape, may have reinforced this image. Even a soldier stationed in south Armagh watchtowers seemed troubled by the contrast. "[s]ome of the scenery there is spectacular and on a beautiful sunny day you'd stand outside, have a cigarette, take in the scenery and not think about the great big bloody eyesore you were stood on" (John [name withheld], interviewed by West, 2007, p. 52).

In Walking Along the Border Colm Tóibín hears the view of a local resident. He meets the man rapt in admiration of slieve Gullion. This is a south Armagh peak that, unlike many of its neighbours, never had a watchtower built on it. He thought it was the most wonderful place in the world and told Tóibín that he would not be responsible for what he would do if the British military put a base or a lookout tower on that particular mountain (Tóibín, 1987, p. 150).

19 Slieve Gullion was never used as a base and now all the other watchtowers are gone as well. As both parts of Ireland evolve in their attitudes to each other, the handling of the borderland has also changed and the architecture of its security has softened. Nationalist parties in Northern Ireland led the attempt to have the watchtowers removed yet when, in 2007, the removal began, a Nationalist politician suggested one tower should be left in place. "I think [the Troubles in south Armagh] should be remembered, and we should retain some of it for future generations so that they can have a better understanding of their history" (Davy Hyland MLA, interviewed by Graham, 2007, p.50). It could be suggested that the propaganda value of those oppressive structures would, it was suddenly realised, be badly missed by people whose ultimate aim, a united Ireland, was still unattained. However, Hyland's view did not win out. The only watchtowers on The Map of Watchful Architecture still standing are an ecclesiastical round tower in Clones and the Eleven Ballyboes signal tower north of Derry. The former was built in the Early Christian period to defend against raiders. The latter was built in the $19^{\text {th }}$ century in case of French incursion. An historical phase unrepresented among the various defensive structures left along the border is, in fact, a most recent one. The relics of two thousand years are there to be seen but the installations of Operation Banner, 1969-2007, have been erased.

20 At the time of writing the management of the Irish border is tending towards the deconstruction of strong points and, instead, working on the building of links. Little interest has been shown in preserving the relics of the Troubles or attempting to establish the kind of 'Troubles tourism' seen in Belfast and Londonderry. Now that the border's association with criminality has been eroded it can become the site of other 
sorts of activities. Much as was the case in Germany, Ireland's loosening border has been found to be an often well-preserved natural environment. Efforts to make southern Co. Armagh, Co. Down and the north of Co. Louth a cross-border 'geopark' are ongoing (Heritage Officer, 2010). Meanwhile many groups and collaborations have appeared to foster cross-border activity. For example, the International Centre for Local and Regional Development is currently engaged in an attempt to twin the towns of Dundalk and Newry, across the border from each other, and to encourage town planners to share their services (ICLRD, 2010, online).

The policing of the border is now normalising along western European lines. Aspects of the Schengen Agreement that cover border control, and allow for the police to cross into other jurisdictions when in pursuit of suspected criminals, have not yet not been applied to the Irish border, but an increasing amount of political pressure is being used to make it so (McAleese, 2010, Belfast Telegraph). It seems that it is only a matter of time until it comes to pass.

Look closely and The Map of Watchful Architecture may have the air of the historical. Despite the amount of borderland activity the map might seem to imply, the immigration control checkpoint marked in north Co. Louth is in fact the only map element currently actively managing the border. Perhaps we are now entering a time when the Irish border could be demarcated on a map by charting connections rather than defensive elements.

\section{Conclusion}

In conclusion, The Map of Watchful Architecture suggests that defensive points contributed to the creation of the border rather than to have been simply placed in reaction to it. Dig down and back through time and almost everything on the map seems to have had a precursor. For example, the military towers of southern Armagh, in the late $20^{\text {th }}$ century, seems to have been predicted by the placement of Norman structures, like Moyra's Castle in 1601. Such towers, in their turn, are often built on the sites of older structures, cashels or ring-forts. Underlying all this building we can detect a constant drive to claim high ground. Even more fundamentally, we may come to suspect that the landscape itself was one suited to the formation of mental borders. Much of the borderland is hilly and much of the rest is water. Rivers make up about two thirds of the border's length and it widens into impressive loughs at both ends. There was something of the frontier right there in the land itself, sometime that history reinforced. The Map of Watchful Architecture charts the points that were planted in this borderland and helped narrow it to a borderline.

\section{BIBLIOGRAPHIE}

Buckley V.-M., 1989. From the darkness to the dawn : the later prehistoric and early Christian borderlands. In The Borderlands. Essays on the History of the Ulster-Leinster Border, Raymond Gillespie 
and Harold O'Sullivan (eds), Institute of Irish Studies at Queen's University, Belfast, 1989, p.

22-41.

Clinton M., 2001. Souterrains of Ireland. Wordwell, Wicklow.

Edwards N., 2005. The Archaeology of Early Medieval Ireland, c. 400 - 1169. In Prehistoric and Early Ireland Volume I, Daibhi O'Croinin, Oxford University Press, p. 235-296.

Fredengren C., 2002. Crannogs: A study of people's interaction with lakes, with particular reference to Lough Gara in north-west Ireland. Wordwell, Wicklow.

Graham R. 2007. Interview with Davy Hyland Sinn Féin MLA, Newry and Armagh, June 2006. In Castles of Ulster, Jonathan Olley (photographs), Factotum, Belfast, 2007, p. 48-51.

Heritage Officer, Louth County Council, 2010. Cross-Border geopark. Telephone conversation, 12 August 2010.

ICLRD, 2010. Newry-Dundalk Twin City Region : Supporting the Implementation of Cross-Border Collaborative Frameworks.http://iclrd.org/web/2009/02/27/newry-dundalk-twin-city-region/ [accessed August 2010].

Lynn C., 1983. Some ‘Early’ ring-forts and crannogs. Journal of Archaeology, 1, p. 47-58.

McAleese D., 2010. Is it time to allow PSNI and Gardai to cross the border? Belfast Telegraph, 1 July 2010.

Mitchell F. \& Ryan M., 1997. Reading the Irish Landscape. Townhouse, Dublin.

Morton P., 1989. Emergency Tour, $3^{\text {rd }}$ Para in South Armagh. William Kimber, London.

Thatcher M., 1976. Speech to Finchley Conservatives. http://www.margaretthatcher.org/document/ 102947 [accessed August 2009].

Tóibín C., 1987. Walking Along the Border. MacDonald \& Co, London.

Purbrick L., 2007. British Watchtowers. In British Watchtowers, Donovan Wylie (photographs), Steidl, Göttingen, 2007, p. 57-70.

West R., 2007. Interview with John, a British Army communications NCO, August 2006. In Castles of Ulster, Jonathan Olley (photographs), Factotum, Belfast, 2007, p. 52-55.

\section{RÉSUMÉS}

The international border between Northern Ireland and the South (the Republic of Ireland) came into beingin 1922, but there are many important historical antecedents to the notion and expression of spatial separation in this borderland. The author identifies historical precedents and links them to recent defensive features in order to generate a 'map of watchful architecture' that includes recent and much older elements.

\section{INDEX}

Keywords : Architecture, Border, Cartography, Defensive, Irish

Mots-clés : architecture, carte, défensif, frontière, Irlandais 


\section{AUTEUR}

\section{GARRETT CARR}

Garrett Carr is a writer and artist living in Belfast. garrettcarr@gmail.com. Publications:

- The Map of Watchful Architecture. In Gary A. Boyd and Denis Linehan Eds., Ordnance: War Architecture and Space, London, Ashgate 2012, Forthcoming.

- Remapping the Irish Border. In Kathleen James-Chakraborty and Sabine Strümper-Krobb Eds., Crossing Borders: Space Beyond Disciplines, Peter Lang, Oxford, 2011, p. 149-158.

Maps in collections:

- The Map of Watchful Architecture 1.0, The Map of Connections 3.0 and The Map of Encounters 2.0 prints purchased by the National University of Ireland, Maynooth.

- The Map of Watchful Architecture 1.0 print purchased by the Arts Council of Northern Ireland. 